\title{
Pollution from automobiles
}

SIR - A recent article by A. Lubinska discusses the relative merits of catalytic converters versus lean-burn engines. In that comparison she states that "The high air/fucl ratio of the lean-burn engine lowers both carbon monoxide and nitrous oxide emissions, but increases hydrocarbon emissions...."

Nitrous oxide, $\mathrm{N}_{2} \mathrm{O}$, is emitted only in small quantities by internal combustion engines, while nitric oxide, $\mathrm{NO}$, is proproduced in large quantities ${ }^{2}$. In addition, $\mathrm{N}_{2} \mathrm{O}$ is inert in the lower $10 \mathrm{~km}$ of the atmosphere while NO plays a major role in both photochemical smog $\left(\mathrm{O}_{3}\right)$ forma-

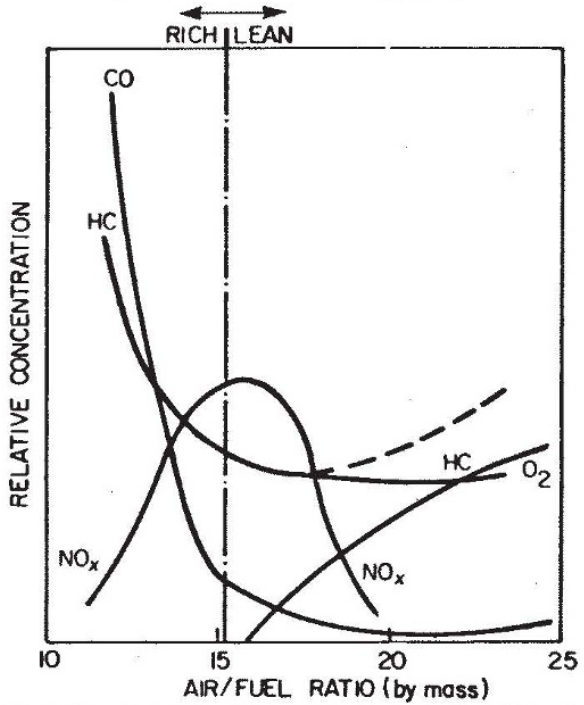

Variation in combustion products as a function of air/fuel ratio ${ }^{4.5}, \mathrm{NO}_{x}$ is the sum of $\mathrm{NO}$ and $\mathrm{NO}_{2}$; these two compounds are rapidly interconverted in the atmosphere. The dashed line shows the result of misfiring.

tion and acid deposition. She appears to have confused the two gases.

More importantly the article tends to oversimplify a complicated issue. Leanburn engines have advanced significantly in recent years, but they are technically complex and not immediately available for mass-production. Not all types of vehicles are suitable for lean-burn engines; the increase in gasoline (motor fuel) economy is accompanied by a decrease in power.

As the air/fuel mixture becomes leaner (higher on figure), $\mathrm{NO}$ emissions increase before they decrease. Lean-burn engines must run at an air/fuel ratio of 22 to 25 before nitric oxide emissions are significantly reduced. At such lean mixtures, ordinary engines misfire and hydrocarbons rise dramatically. A lean-burn engine must have an efficient fuel-injection system to avoid misfiring ${ }^{6}$. The more advanced fuel injection system and other modifications add to the price of an automobile, expenses neglected in Lubinska’s article.

Catalytic converters are more readily available than lean-burn engines but even the implementation of catalysts in European cars is non-trivial. They have been used successfully in the United States but Europe offers more extreme driving conditions. There are more congested cities where the catalyst tends to be too cold and autobahns where routine speeds approach $160 \mathrm{~km}$ per hour (100 miles per hour) and the catalyst tends to be too hot.

Lead, even in very small amounts, poisons catalytic converters. In the United States, unleaded gasoline is federally mandated and nearly all driving is within national boundaries. In Europe, where drivers frequently cross national borders, lead-free gasoline may not be uniformly available.

In summary, lean-burn engines are a promising alternative to catalytic converters, but they too have problems. The reduction of air pollution from automobiles is not simple, and a variety of techniques is sure to be needed.

RUSSELL R. DICKERSON Department of Meteorology,

University of Maryland, College Park, Maryland 20742, USA

1. Lubinska, A. Nature 314, 304 (1985)

2. Weiss, R.F. J. geophys. Res. 86, 7185-7195 (1981)

3. Stedman, D.H. \& Shetter, R.E. Trace Atmospheric Constituents: Properties Transformations and Fates (ed. Schwartz, S.E.) 411-454 (Wiley, New York, 1983).

Agnew, W. Proc. R. Soc. A307, 153 (1968)

5. Olson, D.R. in Air Pollution IV (ed. Stern, A.C.) 595-654 (Academic, New York, 1977)

6. Kobayashi, N., Akatsuka, T., Nakano, J., Kamo, T. \& Matshushita, S. JSAE, Rev. 14, 106-111 (1984).

\section{Research councils}

SIR - Whatever the faults of Whitehall, it is never lost for ideas to make research councils more efficient. Last year the Comptroller and Auditor General ${ }^{1}$ warned that by appointing the best candidate for the job, the research councils were being flooded with staff of unnecessarily high calibre. This was part of the wider problem of fluid grading. Several research councils, although not the Medical Research Council (MRC), were guilty of basing promotion on the ability of the individual, rather than the name of the job. These suggestions were made in all seriousness and the research councils have duly promised to mend their ways.

It has now been realized that what research councils need, to make them more effective, is flexibility through more shortterm and fewer career appointments ${ }^{2}$. It is well known that a civil servant who shows signs of starting to understand a job must be moved on as quickly as possible. This strategy, which has done so much for the British civil service, could well be expected to transform the work of the research councils.

There are one or two difficulties. The Advisory Board for the Research Councils has itself pointed out ${ }^{2}$ that scientists on short-term contracts tend to spend the first half of their time learning to do the work and the second half looking for C)1985 Nature Publishing Group another job. Moreover, the absence of any prospect of employment after the age of 35 could conceivably deter first class candidates from applying. The research councils hope that with some alteration of pension arrangements those on short-term appointments will move on to jobs in industry though, outside a few narrow specialties, it is far from certain that this is what industry wants.

PhDs with postdoctoral experience are deemed overqualified for the majority of jobs in industry. Most of the remaining jobs require industrial rather than research council experience. As an indicattion, over the past 3 years, $230 \mathrm{MRC}$ scientists came to the end of short-term appointments; 13 obtained permanent appointments with MRC and 14 obtained jobs in industry. Most of the remainder went on to yet another short-term appointment. It would be no harm if MRC were permitted to let short-term staff benefit from the pension contributions made on their behalf, rather than to use these contributions, as at present, to subsidize the pensions of other staff members, but it is doubtful if this would fully compensate for such appalling career prospects.

Scientists vote with their feet, and short-term appointments tend to produce few applicants, often of indifferent ability. Permanent appointments attract large numbers of applicants, many of outstanding ability. It has never been explained why it is thought that employing less able scientists on disadvantageous terms will produce greater flexibility and effectiveness than employing more able scientists on advantageous terms. Perhaps the only moral is that the research councils are capable of mismanaging their affairs quite badly enough without the assistance of Whitehall.

Michael Green Chairman, AUT/MRC Committee $M R C$ Cell Mutation Unit,

University of Sussex,

Brighton BN1 9RR, UK

1. Comptroller and Auditor General. Control of Manpower in Non-departmental Government Bodies Sponsored by the Department of Education and Science (HMSO, London, 1984).

. Fixed-term Contracts for Scientists in the Research Councils: Report to the Secretary of State for Education and Science (Advisory Board for the Research Councils, 1985).

\section{Embryo research}

SIR - In the controversy over the status of the human embryo, there exists a state of doubt: some say it is a human being, others say it is not. The views seem fairly equally balanced.

In this impasse, the next step is to examine the consequences should one side or the other eventually be proved to be indisputably correct. On the one side we risk losing a valuable research opportunity - on the other we risk committing murder.

D.A.DARCY

7 Granville Road,

Sevenoaks, Kent, UK 